\title{
Influence of Brand Trust, Perceived Value on Brand Preference and Purchase Intention
}

\author{
Tri Cuong DAM ${ }^{1}$
}

Received: August 01, 2020 Revised: September 06, 2020 Accepted: September 10, 2020

\begin{abstract}
The aim of this research was to empirical examine the influence of brand trust, perceived value on brand preference, and purchase intention for branded phones. The samples were gathered by a convenient sampling method. We collected data from 285 consumers who were visiting electronic supermarkets in Ho Chi Minh City, Vietnam. The measurement used a 5-point Likert scale ranging from 1=completely disagree, and $5=$ completely agree. PLS - Partial Least Squares method was performed to analyze the measurement model and the structural model. The study model was proposed from prior research. We had assessed the reliability of the scales through Cronbach's alpha and composite reliability. As well, we also had evaluated discriminant validity through the Fornell-Larcker criterion. The findings of the study demonstrated that brand trust had a significantly positive influence on brand preference. Likewise, the findings of the research also stated that brand trust had a positive impact on purchase intention. The results revealed that perceived value had a positive effect on brand preference. Furthermore, the outcomes show that perceived value had a positive influence on purchase intention as well. Furthermore, the findings of the research showed that brand preference had a positive effect on purchase intention.
\end{abstract}

Keywords: Brand Trust, Perceived Value, Brand Preference, Purchase Intention, SEM-PLS

JEL Classification Code: C38, M30, M31, M37

\section{Introduction}

Purchasing intention has been one of the principal topics examined in the marketing literature, and triggered the interest of marketing scholars on purchase intention coming from buying behavior. Besides, practitioners also have studied purchase intention to predict transactions of current and new goods/services. Purchase intention information could support practitioners in their marketing decisions linked to goods (new and current), market segmentation, and promotion plans (Tsiotsou, 2006). Therefore, how to get customers to purchase commodities has become essential to marketers because customers have more opportunities to

${ }^{1}$ First Author and Corresponding Author. Lecturer, Faculty of Business Administration, Industrial University of Ho Chi Minh City, Vietnam [Postal Address: 12 Nguyen Van Bao Street, Ward 4, Go Vap District, Ho Chi Minh City, 700000, Vietnam]

Email: damtricuong@iuh.edu.vn

(c) Copyright: The Author(s)

This is an Open Access article distributed under the terms of the Creative Commons Attribution Non-Commercial License (https://creativecommons.org/licenses/by-nc/4.0/) which permits unrestricted non-commercial use, distribution, and reproduction in any medium, provided the original work is properly cited. choose the goods in a competitive and fluctuating business context recently (Choi et al., 2020).

Moreover, trust has been one of the essential elements of long-term and reliable connections between persons. Personal relationships were often employed as a comparison when describing the connection between the brand and the purchaser (Fournier, 1998). In this view, brand trust unveiled its vital importance in individual relationships and the building of a lasting connection between the brand and the purchaser (Aydin \& Taskin, 2014). Some scholars said that brand trust was a precursor of brand preference (Afsar, 2014; Chinomona et al., 2013) and purchase intention (Aydin et al., 2014; Chae et al., 2020).

On the other hand, previous research revealed that perceived value was an antecedent of brand preference (Hellier et al., 2003; Muzakir \& Damrus, 2018) and purchase intention (Calvo-Porral \& Lévy-Mangin, 2017; Hu, 2011). Brand preference was the component that pushed consumers to buy the brand and to repeat this activity (Ebrahim et al., 2016; Soenyoto, 2015). Besides, some empirical studies confirmed that brand preference was a predictor of purchase intention (Chen \& Chang, 2008; Emor \& Pangemanan, 2015; Pool et al., 2018). 
Prior studies involving phones brands such as Vazifehdoost el al. (2014) declared that brand experience, trust in brand, pleasure with brand, and symbolic brand value had direct effects on loyalty to brand (Vazifehdoost et al., 2014). Khundyz (2018) affirmed that brand image, customer satisfaction, brand trust, and promotion had direct impacts on brand loyalty (Khundyz, 2018). Surucu et al. (2020) disclosed that factors, such as brand trust and reference groups, affected the purchasing intention of young adults, in which the reference group was a key factor causing the purchasing intentions of young adults (Surucu et al., 2020). Other scholars examined the impact of attitudes on clients' intention to participate in online fashion sharing (Won \& Kim, 2020). In Vietnam, Wollenberg and Thuong (2014) disclosed that factors (advertising, word of mouth, perceived quality, price) had positive influences on brand perception. The authors also said that advertising, word of mouth, perceived quality, price, and brand perception had direct effects on customer purchasing decisions (Wollenberg \& Thang, 2014). However, there have not been many scholars examining the impact of brand trust and perceived value on brand preference and purchase intention, especially in branded phones in Vietnam. Therefore, in this current empirical study, we analyze the influence of brand trust and perceived value on brand preference and purchase intention for branded phones.

\section{Literature Review and Hypotheses}

\subsection{Purchase Intention}

Fishbein and Ajzen (1975) stated that purchase intention was the consumer's real intention towards commoditizes (Fishbein \& Ajzen, 1975). Purchase intention was considered as the mix of consumers' concerns and the chance of buying the goods. Some previous research acknowledged that purchase intention related sharply to attitude and preference toward the brand or the product (Kim \& Ko, 2012; Martín-Consuegra et al., 2018). Kotler (2003) demonstrated that purchase intention could also be affected by an individual's perceptions and unforeseeable situations. An individual's opinions related to private preference and unforeseen circumstances pointed to the conditions that change the purchase intention (Kotler, 2003). Furthermore, other scholars posited that buying intention was defined as the tendency of the consumers to purchase the goods. The more a customer would like to buy a product, the higher the purchase intention (Dodds et al., 1991; Schiffman \& Kanuk, 2000).

\subsection{Brand Trust}

In the branding literature, the concept of brand trust is based on the perspective of a brand-consumer relationship (Zehir et al., 2011). There have been several concepts of brand trust in the current branding literature (Shin et al.,
2019). Trust was considered as consumers' confidence in the quality and trustworthiness of the products provided by the seller (Garbarino \& Johnson, 1999). Chaudhuri and Holbrook (2001) revealed that brand trust was acknowledged as the clients' readiness to rely on the sense of the brand to deliver its declared goal (Chaudhuri \& Holbrook, 2001). Likewise, brand trust is an expression of believing while connecting with the brand relies on the thinking that the brand will continue to be reliable and satisfying the purchaser (Delgado-Ballester et al., 2003). The concept of trust is only proper in the circumstances of risk (e.g., in case of wider or smaller variety amongst brands). Accurately, trust declined in the situations where the buyer perceived the goods to be very unsafe as they knew they could rely on the trusted brand (Chaudhuri \& Holbrook, 2001; Doney \& Cannon, 1997). The brand trust also was defined as a purchaser's willingness to depend on the brand from the viewpoint of uncertainty since anticipating that the brand will deliver positive outcomes (Lau \& Lee, 1999).

Some scholars stated that, when consumers increased trust in a particular brand, repurchasing was likely to happen, starting to brand preference (Chinomona et al., 2013; Sheth \& Parvatijar, 1995). Previous research demonstrated that brand trust was a predictor of brand preference (Afsar, 2014; Chinomona et al., 2013). Furthermore, there was an impact between brand trust and purchase intention, which indicates if brand trust has developed, then the rate of purchase intention will grow (Aydin et al., 2014; Sanny et al., 2020). Prior studies confirmed that brand trust had a positive effect on purchase intention (Aydin et al., 2014; Sanny et al., 2020). Therefore, we suggested the following hypotheses:

\section{H1: Brand trust has a positive effect on brand preference. H2: Brand trust has a significant influence on purchase intention.}

\subsection{Perceived Value}

Perceived value was the concept that has been attracted researchers (Hanaysha, 2018; Zeithaml, 1988). Perceived value has been studied from four different angles. First, the value was the price. In other words, the value could be regarded the same as price. Second, the value was what I got for what I paid. Thirdly, the value was the trade-off between the quality of the goods and the price. The second and third meanings represented the fundamental role of value in the process of exchange and described the tradeoff between cost and benefit. Finally, the value was an overall evaluation of a target of subjective judgment with the attention of evaluation criteria (Pan \& Kang, 2017; Zeithaml, 1988). Other scholars stated that the perceived value, in the narrowest sense, was the price paid for the product/service. More broadly, the perceived value was the sum that purchasers paid to get the benefits of having or 
utilizing the product/service (Kotler \& Armstrong, 2016). Perceived value also was defined as consumers' general evaluation of the product's benefits with the expense and time that they gave to get the product (Hellier et al., 2003).

Prior research showed that perceived value was a crucial antecedent of brand preference (Ebrahim et al., 2016; Hellier et al., 2003; Muzakir \& Damrus, 2018) and had a positive influence on brand preference (Ebrahim et al., 2016; Hellier et al., 2003; Muzakir \& Damrus, 2018). Besides, some studies indicated that perceived value was a precursor of purchase intention (Calvo-Porral \& Lévy-Mangin, 2017; Y. Hu, 2011). Prior empirical researches revealed that perceived value had a positive influence on purchase intention (Calvo-Porral \& Lévy-Mangin, 2017; Hsieh, 2016; Hu, 2011). Therefore, we proposed the next hypotheses:

\section{H3: Perceived value has a significant impact on brand preference.}

H4: Perceived value has a positive influence on purchase intention.

\subsection{Brand Preference}

Brand preference is a notion that has interested scholars recently (Pool et al., 2018; Vongurai, 2020). Brand preference was defined as customers' tendency towards certain brands that review their cognitive information processing towards brand stimuli. This concept highlighted the central control unit and the mental abilities of customers (Bettman et al., 1975; Ebrahim et al., 2016). Therefore, this indicated that a purchaser's perception of brand attributes leads to preferences or attitudes, which impacts his/her intentions and brand choices (Bagozzi, 1982). The preference described a shifting phase between the inputs and outputs of the purchaser choice model. It was the link between information processing and the intention to purchase or choose (Bagozzi, 1983). Brand preference was considered as a behavioral propensity that reveals a purchaser's attitude towards a brand (Ebrahim et al., 2016). Brand preference has been one of the customer judgment formed toward a brand. It was a state where the purchaser preferred a particular brand as they had positive feelings toward the brand. Brand preference usually happened in the alternative assessment step of customer decision making (Kotler \& Keller, 2016).

Besides, some scholars suggested that brand preference was a crucial antecedent to purchase intention and had a positive influence on purchase intention (Chen \& Chang, 2008; Emor \& Pangemanan, 2015; Pool et al., 2018). Therefore, we suggested the following hypothesis:

\section{H5: Brand preference has a positive impact on purchase intention.}

Based on the research, literature review and hypotheses development, Figure 1 shows the proposed research model.

\section{Research Methodology}

\subsection{Sample and Data Collection}

The data was an analysis of consumers who drop by at electronic supermarkets and want to purchase branded phones in Ho Chi Minh, Vietnam. This research sample was conducted through convenience sampling with different groups of customers across gender and age in Ho Chi Minh City, Vietnam. We sent a total of 400 questionnaires; 347 questionnaires were returned, and 62 questionnaires were disregarded, as there was no adequate information. There were 285 questionnaires used for the last analysis. The sample was 121 male consumers (42.5\%) and 164 female consumers (57.5\%). Customers in the age group 18 to 25 made up $31.9 \%$ of the respondents, $30.9 \%$ were in the age group 26 to 35 , $26,0 \%$, in the age group 36 to 45 , and $11.2 \%$ were older.

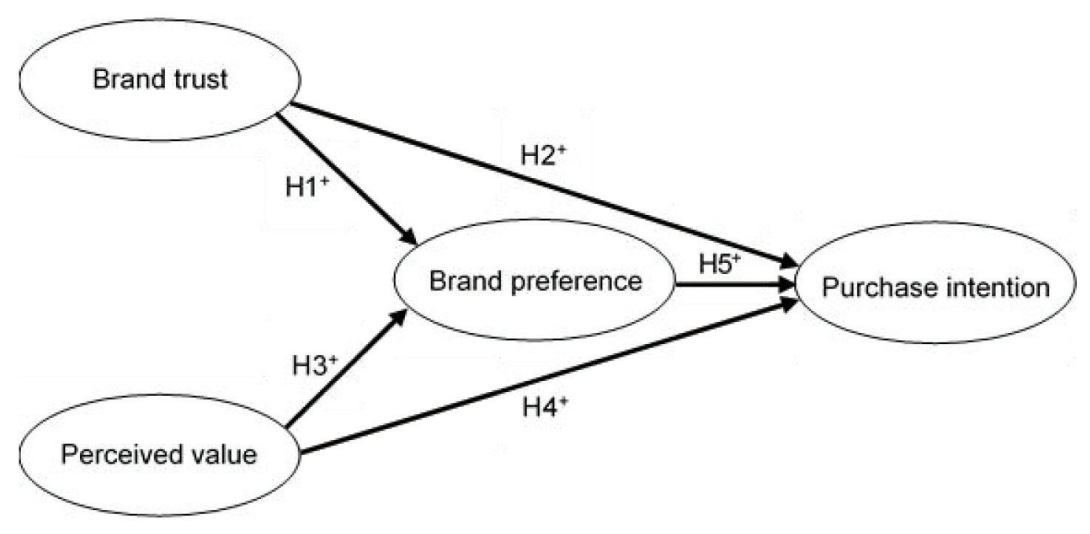

Figure 1: The proposed research model 


\subsection{Measurements}

The measurement items of the constructs from previous research were reviewed and adapted to suit the study circumstance. A 5-point Likert scale ranging from " 1 = completely disagree" to " $5=$ completely agree" was performed. In this present research, we adapted four items of brand trust from Chaudhuri and Holbrook (2001); Lau and Lee (1999); four items of perceived value from So et al. (2013); Baek and King (2011); Baek and King (2011); four brand preference from Afsar (2014); Chinomona et al. (2013); and four items of purchase intention from Choi et al. (2020); Mathur (1999).

\subsection{Analytical Method}

The partial least squared (PLS) method was used in this research because this method is appropriate in any of the following contexts, such as (1) predicting the primary statistical objective of the study, (2) applying with small samples and non-normal distributions data, as was typical of social science and survey data, (3) studying includes many latent variables, (4) ability to assess complex models with many constructs and many indicators, (5) capacity to apply formative composite measures, (6) suitable for exploratory research predicting endogenous constructs, and (7) fitting with the latent variable measurement models are measured formatively (Hair et al., 2017; Manley et al., 2020). Besides, the PLS method has gained increasing popularity as a critical multivariate analysis method in different research fields such as marketing, operations management, and management information systems (Hair et al., 2017; Hair et al., 2013). We employed the partial least squared structural equation modeling (PLS-SEM) with SmartPLS software to measure the proposed research model and hypotheses. Testing the proposed research model and suggestions were taken through two stages: (1) evaluation of the measurement model and (2) evaluation of the structural model (PLSSEM) (Hair et al., 2017).

\section{Results and Discussion}

\subsection{Results}

\subsubsection{Evaluation of the Measurement Model: Construct Reliability and Validity}

Table 1 presents the measurement scale of the construct's research results. We applied Cronbach's Alpha and composite reliability (CR) for assessing the reliability of the research. Cronbach's alpha $(\alpha)$ values of the constructs should be higher than 0.70 , and the $\mathrm{CR}$ values higher than 0.70 , meaning there is enough internal consistency of the constructs (Hair et al., 2017). Table 1 illustrates that Cronbach's alpha values of the independent variables were above 0.70 . Therefore, these constructs have internal consistency reliability.

We applied the factor loading of all items values and the average variance extracted (AVE) to evaluate convergent validity. The factor loading and AVE should be higher than 0.50 (Bagozzi \& Yi, 1988; Hair et al., 2017). In this current research, the factor loading of all items and the AVE values were above 0.50 . Accordingly, the convergent validity of the constructs was fit.

Furthermore, we assessed discriminant validity through the Fornell-Larcker criterion (Fornell \& Larcker, 1981). It depicted the square root of the AVE values with the latent variable. Specifically, the square root of the AVE should be higher than its highest correlation with any other concept. (Hair et al., 2017). Table 2 shows that the square root of AVE of reflective construct brand trust, perceived value, brand preference, and purchase intention was higher than the corresponding latent variables correlation. Hence, the discriminant validity of these constructs was good.

\subsubsection{Assessment of the Structural Model and Hypotheses Testing}

\section{Evaluation of the model fit}

Table 3 presents the model fit results. The results in Table 3 described that the Chi-square $=389.129$ was significant at 0.05 level $(\mathrm{p}=0.00)$. SRMR (standardized root mean square residual) was a measure of the approximate model fit of the proposed research model. By convention, a model had a good model fit when SRMR was less than 0.08 (Hu \& Bentler, 1998). The summary results in Table 3 exposed that this model had SRMR indices $=0.062<$ 0.08 . Hence, the suggested research model was appropriate well for investigation data. Furthermore, measuring of a multicollinearity issue revealed that all VIF values were below the threshold of 5 . Consequently, there were no multicollinearity problems in the structural model (Hair et al., 2017).

\section{Hypotheses testing}

Table 4 shows the hypotheses testing findings. Bootstrapping outcomes (with 5000 resamplings) for the association between the notions in the suggested study model demonstrated that the t-value of the H1, H2, H3, H4, H5 was higher than 1.96, and these hypotheses were meaningful at a $5 \%$ level. As a result, these hypotheses were supported. 
Table 1: Measurement items of the construct's analysis results

\begin{tabular}{|c|c|c|c|c|}
\hline Constructs and measurement items & Factor loading & a & CR & AVE \\
\hline Brand trust & & 0.795 & 0.867 & 0.620 \\
\hline 1. I trust this phone brand & 0.718 & & & \\
\hline 2. I feel that I can trust this phone brand completely & 0.797 & & & \\
\hline 3. I can rely on this phone brand & 0.828 & & & \\
\hline 4. This brand is secure when I buy this phone brand & 0.802 & & & \\
\hline Perceived value & & 0.852 & 0.900 & 0.693 \\
\hline 1. The phone appears to be a good value for the price & 0.833 & & & \\
\hline 2. The price is given that this phone brand is very acceptable. & 0.838 & & & \\
\hline 3. This phone brand is supposed to be a good financial deal. & 0.842 & & & \\
\hline 4. The price of this phone brand is competitive. & 0.816 & & & \\
\hline Brand preference & & 0.758 & 0.846 & 0.580 \\
\hline 1. I feel that this phone brand is appealing to me & 0.761 & & & \\
\hline 2. I prefer this phone brand to other brands of its type & 0.804 & & & \\
\hline 3. I prefer this phone brand if everything else is equal & 0.762 & & & \\
\hline 4. In general, I prefer this phone brand & 0.716 & & & \\
\hline Purchase intention & & 0.841 & 0.894 & 0.678 \\
\hline 1. I would intent to buy the brand in the future. & 0.772 & & & \\
\hline 2. I would plan to purchase this phone brand. & 0.849 & & & \\
\hline 3. I would attempt to purchase this brand. & 0.836 & & & \\
\hline 4. I would certainly purchase this brand. & 0.834 & & & \\
\hline
\end{tabular}

Table 2: Discriminant validity result

\begin{tabular}{|l|c|c|c|c|}
\hline & Brand preference & Brand trust & Perceived value & Purchase intention \\
\hline Brand preference & 0.761 & & & \\
\hline Brand trust & 0.672 & 0.787 & & \\
\hline Perceived value & 0.668 & 0.691 & 0.832 & \\
\hline Purchase intention & 0.682 & 0.665 & 0.676 & 0.823 \\
\hline
\end{tabular}

Table 3: Model fit results

\begin{tabular}{|l|c|}
\hline & Saturated model \\
\hline SRMR & 0.062 \\
\hline d_ULS & 0.530 \\
\hline d_G1 & 0.245 \\
\hline d_G2 & 0.232 \\
\hline Chi-Square & 389.129 \\
\hline NFI & 0.834 \\
\hline
\end{tabular}


Table 4: Hypotheses testing results

\begin{tabular}{|l|c|c|c|c|c|}
\hline Relationship & Hypotheses & $\begin{array}{c}\text { Path } \\
\text { coefficients }\end{array}$ & t-value & p-value & Results \\
\hline Brand trust $\rightarrow$ Brand preference & H1 & 0.402 & 6.136 & 0.000 & approved \\
\hline Brand trust $\rightarrow$ Purchase intention & H2 & 0.250 & 3.835 & 0.000 & approved \\
\hline Perceived value $\rightarrow$ Brand preference & H3 & 0.390 & 6.815 & 0.000 & approved \\
\hline Perceived value $\rightarrow$ Purchase intention & H4 & 0.288 & 4.307 & 0.000 & approved \\
\hline Brand preference $\rightarrow$ Purchase intention & H5 & 0.321 & 4.620 & 0.000 & approved \\
\hline
\end{tabular}

Table 5: $\mathrm{R}^{2}, \mathrm{f}^{2}$, and $\mathrm{Q}^{2}$ results

\begin{tabular}{|c|c|c|c|c|c|}
\hline Relationship & $\begin{array}{c}\text { Path } \\
\text { coefficients }\end{array}$ & $f^{2}$ & Construct & $\mathbf{R}^{2}$ & $\mathbf{Q}^{2}$ \\
\hline Brand trust $\rightarrow$ Brand preference & 0.402 & 0.181 & \multirow{2}{*}{$\begin{array}{c}\text { Brand } \\
\text { preference }\end{array}$} & \multirow{2}{*}{0.531} & \multirow{2}{*}{0.281} \\
\hline Brand trust $\rightarrow$ Purchase intention & 0.250 & 0.066 & & & \\
\hline Perceived value $\rightarrow$ Brand preference & 0.390 & 0.170 & \multirow{3}{*}{$\begin{array}{l}\text { Purchase } \\
\text { intention }\end{array}$} & \multirow{3}{*}{0.580} & \multirow{3}{*}{0.362} \\
\hline Perceived value $\rightarrow$ Purchase intention & 0.288 & 0.088 & & & \\
\hline Brand preference $\rightarrow$ Purchase intention & 0.321 & 0.115 & & & \\
\hline
\end{tabular}

\section{$R^{2}$ (explained variance), $f^{2}$ (effect size) and $Q^{2}$ (predictive relevance)}

The structural model is examined with the main evaluation metrics $\mathrm{R}^{2}$ (explained variance), $\mathrm{f}^{2}$ (effect size), and $\mathrm{Q}^{2}$ (predictive relevance) (Hair et al., 2017). The coefficient of determination $\left(\mathrm{R}^{2}\right)$ was the overall effect extent measure for the structural model (Garson, 2016). The $\mathrm{R}^{2}$ value is between 0 to 1 , with higher levels indicating more predictive accuracy. The $\mathrm{R}^{2}$ value of $0.19,0.33$, and 0.67 could be presented as weak, moderate, and substantial (Chin, 1998). The $\left(\mathrm{f}^{2}\right)$ effect size enabled evaluating the independent variable contribution to the dependent variable. The $\mathrm{f}^{2}$ value 0.02 was small, 0.15 was medium, and 0.35 was high (Cohen, 1988). The $\mathrm{Q}^{2}$ value estimated the structural model's predictive relevance for each endogenous construct. The $\mathrm{Q}^{2}$ value should be over zero (Hair et al., 2017).

In this current study, the $\mathrm{R}^{2}$ value for the overall model was 0.580 (see Table 5), less than 0.67 , regarded as a fairly substantial impact; we noticed that brand preference had the strongest influence (0.321), followed by the perceived value (0.288), and brand trust (0.250). Furthermore, brand trust and perceived value explained $53.1 \%$ of the variance on brand preference; we also unveiled that brand trust had a more substantial effect (0.402) than the perceived value (0.390).

Table 5 shows the $\mathrm{f}^{2}$ effect sizes. The medium $\mathrm{f}^{2}$ effect size happened for the relationship of brand trust $\rightarrow$ brand preference (0.181), and perceived value $\rightarrow$ brand preference
(0.170). The medium-weak $\mathrm{f}^{2}$ effect size occurred for the link of brand preference $\rightarrow$ purchase intention (0.115). The small $\mathrm{f}^{2}$ effect size happened for the connection perceived value $\rightarrow$ purchase intention (0.088), and brand trust $\rightarrow$ purchase intention (0.066).

Table 5 also shows that the $Q^{2}$ values of two endogenous variables were over zero. Precisely, brand preference had $\mathrm{Q}^{2}$ values $(0.281)$, and purchase intention had $\mathrm{Q}^{2}$ values $(0.362)$. These results confirmed the model's predictive power is suited for the endogenous latent variables.

\subsection{Discussion}

This present research's contribution was to examined and measured the influence of brand trust and perceived value on brand preference and purchase intention for branded phones in a different circumstance from previous research. Most of the prior studies focus on these impacts for the various industries, and this current study demonstrated these effects in the Vietnam electronic supermarket market.

The current study results show that the five hypotheses in the research model were supported. The research results illustrate that brand trust had a positive impact on brand preference. Brand trust was an antecedent to brand preference. The $\mathrm{f}^{2}$ impact size of the relationship between brand trust and brand preference was moderate $(0.181)$. The prior empirical research reinforced the findings of this study (Afsar, 2014). The research findings also showed that brand 
trust had a significant positive effect on purchase intention. Brand trust was a precursor of purchase intention. The $\mathrm{f}^{2}$ effect size of the link between brand trust and purchase intention was small (0.066). The previous empirical studies confirmed the results of this research (Aydin et al., 2014; Sanny et al., 2020).

Besides, the study results also pointed out that perceived value had a positive impact on brand preference. Perceived value was a predecessor of brand preference, and the $\mathrm{f}^{2}$ effect size of the connection of the perceived value and brand preference was medium (0.170). The previous empirical investigations confirmed the results of this research (Ebrahim et al., 2016; Hellier et al., 2003; Muzakir \& Damrus, 2018). Likewise, the study outcomes also noted that perceived value had a positive influence on purchase intention. Perceived value was an antecedent of purchase intention, and the $f^{2}$ effect size of the link of the perceived value and purchase intention was small (0.088). The prior empirical studies reinforced the results of this research (Calvo-Porral \& LévyMangin, 2017; Hsieh, 2016; Hu, 2011).

Moreover, the findings also reveal that brand preference had a positive effect on purchase intention. Brand preference was a precursor of purchase intention, and the $\mathrm{f}^{2}$ effect size of the tie of brand preference and purchase intention was medium-weak (0.115). The earlier empirical research verified the outcomes of this research (Chen \& Chang, 2008; Emor \& Pangemanan, 2015; Pool et al., 2018).

\section{Conclusions and limitations}

In line with the prior studies, this current study documents the influence of brand trust, perceived value on brand preference, and purchase intention for branded phones. Thus, practitioners should focus on strategies that improve the consumer's perception of brand trust, perceived value, and brand preference to increase purchase intention. Managers also should note brand trust has a more essential role in brand preference than perceived value. The study results illustrated that brand trust was a predictor of brand preference and purchase intention. The research will help electronic supermarket managers to recognize the significance of brand trust on brand preference and purchase intention. Therefore, managers should build strategies to increase customers' brand trust. If consumers trust the product brand, consumers have express a positive tendency for brand preference and purchase intention. Likewise, the findings demonstrated that perceived value was an antecedent to brand preference and purchase intention. The research will help practitioners to understand the importance of perceived value on brand preference and purchase intention. Therefore, managers should build strategies to increase clients' perceived value, such as to improve good value for the price in the context of the price competition. If clients' perceived value increases, clients will increase brand preference and purchase intention. Finally, the results also revealed that brand preference was an antecedent of purchase intention. Therefore, managers should create marketing programs to improve brand preference, in turn, which leads to enhance purchase intention.

Though this current research has made an essential contribution to the literature and practice, it has some limitations. First, this ongoing research may not be generalizable to all other industries, so future research should focus on other sectors such as fashion, computers, etc. Second, this study looks only on the effect of brand trust and perceived value on brand preference and purchase intention for branded phones; therefore, future studies should focus on other influential factors such as brand image, brand awareness, brand love, etc.

\section{References}

Afsar, B. (2014). Effect of perceived Price, Brand Image, perceived Quality and Trust on Consumer's buying Preferences. Journal of Economics and Business Research, 1, 7-20.

Aydin, G., AR, A. A., \& Taskin, C. (2014). The Role of Brand Trust on Parents Purchase Intentions of Baby-Care Products. Doğuş Üniversitesi Dergisi, 2(15), 165-180. https://doi.org/10.31671/ dogus. 2018.84

Baek, T. H., \& King, K. W. (2011). Exploring the consequences of brand credibility in services. Journal of Services Marketing, 25(4), 260-272. https://doi.org/10.1108/08876041111143096

Bagozzi, R. P. (1982). A Field Investigation of Causal Relations among Cognitions, Affect, Intentions, and Behavior. Journal of Marketing Research, 19(4), 562-583.

Bagozzi, R. P. (1983). A holistic methodology for modeling consumer response to innovation. Operations Research, 31(1), 128-176. https://doi.org/10.1287/opre.31.1.128

Bagozzi, R. P., \& Yi, Y. (1988). On the Evaluation of Structural Equation Models. Academy of Marketing Science, 16(1), 74-94.

Bettman, J. R., Capon, N., \& Lutz, R. J. (1975). Multiattribute Measurement Models and Multiattribute Attitude Theory: A Test of Construct Validity. Journal of Consumer Research, 1(4), 1-15. https://doi.org/10.1086/208602

Calvo-Porral, C., \& Lévy-Mangin, J. P. (2017). Store brands' purchase intention: Examining the role of perceived quality. European Research on Management and Business Economics, 23(2), 90-95. https://doi.org/10.1016/j.iedeen.2016.10.001

Chae, H., Kim, S., Lee, J., \& Park, K. (2020). Impact of product characteristics of limited edition shoes on perceived value, brand trust, and purchase intention; focused on the scarcity message frequency. Journal of Business Research, 1-9. https:// doi.org/10.1016/j.jbusres.2019.11.040

Chaudhuri, A., \& Holbrook, M. B. (2001). The Chain of Effects from Brand Trust and Brand Affect to Brand Performance: The Role of Brand Loyalty. Journal of Marketing, 65(2), 81-93. 
Chen, C. F., \& Chang, Y. Y. (2008). Airline brand equity, brand preference, and purchase intentions-The moderating effects of switching costs. Journal of Air Transport Management, 14(1), 40-42. https://doi.org/10.1016/j.jairtraman.2007.11.003

Chin, W. W. (1998). The partial least squares approach to structural equation modeling. In G. A. Macoulides (Ed.), Modern Methods for Business Research (pp. 295-336). Mahwah, NJ: Lawrence Erlbaum Associates.

Chinomona, R., Mahlangu, D., \& Pooe, D. (2013). Brand service quality, satisfaction, trust and preference as predictors of consumer brand loyalty in the retailing industry. Mediterranean Journal of Social Sciences, 4(14), 181-190. https://doi. org/10.5901/mjss.2013.v4n14p181

Choi, N. H., Qiao, X., \& Wang, L. (2020). Effects of multisensory cues, self-enhancing imagery and self goal-achievement emotion on purchase intention. Journal of Asian Finance, Economics and Business, 7(1), 141-151. https://doi. org/10.13106/jafeb.2020.vol7.no1.141

Cohen, J. (1988). Statistical power analysis for the behavioral sciences. Mahwah, NJ: Lawrence Erlbaum Associates.

Cuong, D. T. (2020a). The Impact of Brand Credibility and Perceived Value on Customer Satisfaction and Purchase Intention at Fashion Market. Journal of Advanced Research in Dynamical and Control Systems, 12(03-Special), 691-700. https://doi.org/10.5373/jardcs/v12sp3/20201308

Cuong, D. T. (2020b). The role of brand trust as a mediator in the relationship between brand satisfaction and purchase intention. International Journal of Psychosocial Rehabilitation, 24(6), 14726-14735.

Delgado-Ballester, E., Munuera-Aleman, J. L., \& Yague-Guillen, M. J. (2003). Development and Validation of a Brand Trust Scale. International Journal of Market Research, 45(1), 35-53. https://doi.org/10.1177/147078530304500103

Dodds, W. B., Monroe, K. B., \& Grewal, D. (1991). Effects of Price, Brand, and Store Information on Buyers' Product Evaluations. Journal of Marketing Research, 28(3), 307. https://doi. org $/ 10.2307 / 3172866$

Doney, M., \& Cannon, J. P. (1997). Trust Examination of the Nature of in Buyer-Seller Relationship for assistance. Journal of Marketing, 61(2), 35-51.

Ebrahim, R., Ghoneim, A., Irani, Z., \& Fan, Y. (2016). A brand preference and repurchase intention model : the role of consumer experience. Journal of Marketing Management, 32(13-14), 12301259. https://doi.org/10.1080/0267257X.2016.1150322

Emor, A., \& Pangemanan, S. (2015). Analyzing Brand Equity on Purchase Intention Through Brand Preference of Samsung Smartphone User In Mandao. Jumal EMBA, 3(2), 124-131.

Fishbein, M., \& Ajzen, I. (1975). Belief, attitude, intention and behavior: An introduction to theory and research. Reading, MA: Addison-Wesley Publishing.

Fornell, C., \& Larcker, D. F. (1981). Evaluating Structural Equation Models with Unobservable Variables and Measurement Error. Journal of Marketing Research, 18(1), 39-50.
Fournier, S. (1998). Consumers and Their Brands: Developing Relationship Theory in Consumer Research. Journal of Consumer Research, 24(4), 343-353. https://doi. org/10.1086/209515

Garbarino, E., \& Johnson, M. S. (1999). The Different Roles of Satisfaction, Trust, and Commitment in Customer Relationships. Journal of Marketing, 63(April), 70-87.

Garson, G. D. (2016). Partial least squares: Regression \& structural equation models (2016 ed.). Asheboro, NC: Statistical Associates Publishers.

Hair, J.F., Hult, G. T. M., Ringle, C. M., \& Sarstedt, M. (2017). A Primer on Partial Least Squares Structural Equation Modeling (PLS-SEM) (2nd ed.). Los Angeles, CA: Sage Publications, Inc.

Hair, Joseph F., Ringle, C. M., \& Sarstedt, M. (2013). Partial Least Squares Structural Equation Modeling: Rigorous Applications, Better Results and Higher Acceptance. Long Range Planning, 46(1-2), 1-12. https://doi.org/10.1016/j.lrp.2013.01.001

Hanaysha, J. R. (2018). Customer retention and the mediating role of perceived value in retail industry. World Journal of Entrepreneurship, Management and Sustainable Development, 14(1), 2-24.

Hellier, P. K., Geursen, G. M., Carr, R. A., \& Rickard, J. A. (2003). Customer repurchase intention. European Journal of Marketing, 37(11/12), 1762-1800. https://doi. org/10.1108/03090560310495456

Hsieh, H.-Y. (2016). The Relationship among Consumer Value, Brand Image, Perceived Value and Purchase Intention-A Case of Tea Chain Store in Tainan City. In: Proceedings of the Eighth Asia-Pacific Conference on Global Business, Economics, Finance and Banking (AP16 Singapore Conference). July. Retrieved from www.globalbizresearch.org

Hu, L., \& Bentler, P. (1998). Fit indices in covariance structure modeling: Sensitivity to underparameterized model misspecification. Psychological Methods, 3(4), 424-453.

$\mathrm{Hu}, \mathrm{Y}$. (2011). Linking perceived value, customer satisfaction, and purchase intention in E-commerce settings. Advances in Intelligent and Soft Computing, 106, 623-628. https://doi. org/10.1007/978-3-642-23753-9_100

Khundyz, Z. (2018). The Influence Factors of Brand Loyalty: Mobile Phone Industry. American Journal of Industrial and Business Management, 8(6), 1624-1633. https://doi. org/10.4236/ajibm.2018.86108

Kim, A. J., \& Ko, E. (2012). Do social media marketing activities enhance customer equity? An empirical study of luxury fashion brand. Journal of Business Research, 65(10), 1480-1486. https://doi.org/10.1016/j.jbusres.2011.10.014

Kotler, P. (2003). Marketing Management (11th ed.). Upper Saddle River, NJ: Prentice Hall.

Kotler, P., \& Armstrong, G. (2016). Principles of Marketing (16th ed.). Harlow: Pearson Education Limited.

Kotler, P., \& Keller, K. L. (2016). Marketing Management (15th ed.). New York, NY: Pearson Education, Inc. 
Lau, G. T., \& Lee, S. H. (1999). Consumers' Trust in a Brand and the Link to Brand Loyalty. Journal of Market Focused Management, 4(1999), 341-370.

Manley, S. C., Hair, J. F., Williams, R. I., \& McDowell, W. C. (2020). Essential new PLS-SEM analysis methods for your entrepreneurship analytical toolbox. International Entrepreneurship and Management Journal. https://doi. org/10.1007/s11365-020-00687-6

Martín-Consuegra, D., Faraoni, M., Díaz, E., \& Ranfagni, S. (2018). Exploring relationships among brand credibility, purchase intention and social media for fashion brands: A conditional mediation model. Journal of Global Fashion Marketing, 9(3), 237-251. https://doi.org/10.1080/20932685.2 018.1461020

Mathur, A. (1999). Incorporating Choice into an Attitudinal Framework. Journal of International Consumer Marketing, 10, 93-110. https://doi.org/10.1300/j046v10n04_06

Muzakir, \& Damrus. (2018). Analysis of Customer Perceived Value and Its Impact on Customer Brand Preference and Future Purchase Intention. Jurnal Bisnis dan Kajian Strategi Manajemen. 2(1), 27-42.

Pan, H., \& Kang, M.-S. (2017). Comparative Analysis of Galaxy and Xiaomi on Switching Intention Process of Smartphone Using Structural Equation Modeling. International Journal of Multimedia and Ubiquitous Engineering, 12(2), 13-28. https:// doi.org/10.14257/ijmue.2017.12.2.02

Pool, J. K., Asian, S., Abareshi, A., \& Mahyari, H. K. (2018). An examination of the interplay between country-of-origin, brand equity, brand preference and purchase intention toward global fashion brands. Internation Journal of Business Forecasting and Marketing Intelligence, 4(1), 43-63.

Sanny, L., Arina, A. N., Maulidya, R. T., \& Pertiwi, R. P. (2020). Purchase intention on Indonesia male's skin care by social media marketing effect towards brand image and brand trust. Management Science Letters, 10, 2139-2146. https://doi. org/10.5267/j.msl.2020.3.023

Schiffman, L. G., \& Kanuk, L. L. (2000). Consumer Behavior. New York, NY: Prentice Hall.

Sheth, J. N., \& Parvatijar, A. (1995). The evolution of relationship marketing. International Business Review, 4(4), 397-418. https://doi.org/10.1108/08876040210447324

Shin, S. K. S., Amenuvor, F. E., Basilisco, R., \& Owusu-Antwi, K. (2019). Brand Trust and Brand Loyalty: A Moderation and Mediation Perspective. Current Journal of Applied Science and Technology, 38(4), 1-17. https://doi.org/10.9734/cjast/2019/ v38i430376
So, K. K. F., King, C., Sparks, B., \& Wang, Y. (2013). The influence of customer brand identification on hotel brand evaluation and loyalty development. International Journal of Hospitality Management, 34(1), 31-41. https://doi.org/10.1016/j. ijhm.2013.02.002

Soenyoto, F. L. (2015). The Impact of Brand Equity on Brand Preference and Purchase Intention in Indonesia's Bicycle Industry : A Case Study of Polygon. IBuss Management, 3(2), 99-108.

Surucu, L., Yesilada, F., \& Maslakci, A. (2020). Purchasing Intention : A Research on Mobile Phone Usage by Young Adults. Journal of Asian Finance, Economics and Business, 7(8), 353360. https://doi.org/10.13106/jafeb.2020.vol7.no8.353

Tsiotsou, R. (2006). The role of perceived product quality and overall satisfaction on purchase intentions. International Journal of Consumer Studies, 30(2), 207-217. https://doi. org/10.1111/j.1470-6431.2005.00477.x

Vazifehdoost, H., Rahnama, A., \& Mousavian, S. J. (2014). Evaluation of the Impact of Brand Purchase Involvement, Satisfaction, Experience and Brand Trust on Loyalty to Brand. Mediterranean Journal of Social Sciences, 5(20), 3054-3063. https://doi.org/10.5901/mjss.2014.v5n20p3054

Vongurai, R. (2020). Factors Affecting Customer Brand Preference toward Electric Vehicle in Bangkok, Thailand. Journal of Asian Finance, Economics and Business, 7(8), 383-393. https://doi. org/10.13106/jafeb.2020.vol7.no8.383

Wollenberg, A., \& Thang, T. T. (2014). Consumer Behaviour in the Smartphone Market in Vietnam. International Journal of Innovation, Management and Technology, 5(6). https://doi. org/10.7763/ijimt.2014.v5.550

Won, J., \& Kim, B. Y. (2020). The effect of consumer motivations on purchase intention of online fashion-sharing platform. Journal of Asian Finance, Economics and Business, 7(6), 197-207. https://doi.org/10.13106/jafeb.2020.vol7.no6.197

Zehir, C., Şahin, A., Kitapçi, H., \& Özçahin, M. (2011). The effects of brand communication and service quality in building brand loyalty through brand trust; The empirical research on global brands. Procedia - Social and Behavioral Sciences, 24(December), 1218-1231. https://doi.org/10.1016/j. sbspro.2011.09.142

Zeithaml, V. A. (1988). Consumer Perceptions of Price, Quality, and Value: A Means-End Model and Synthesis of Evidence. Journal of Marketing, 52(3), 2-22. https://doi. org/10.1177/002224298805200302 